\title{
Correction to: Unbiased decision making in location-routing problems with uncertain customer demands
}

\author{
Annarita De Maio ${ }^{1,3} \cdot$ Roberto Musmanno ${ }^{1}$. Francesca Vocaturo ${ }^{2}$
}

(C) The Author(s) 2022

\section{Correction to: Soft Computing}

https://doi.org/10.1007/s00500-022-06785-7

While typesetting the article the author Roberto Musmanno should have only one affiliation instead of two affiliations. The correct affiliation has been copied below

Department of Mechanical, Energy and Management Engineering - DIMEG, University of Calabria, Via P. Bucci, Cubo 41C, 87036, Arcavacata di Rende, CS, Italy

The original article has been corrected.

Open Access This article is licensed under a Creative Commons Attribution 4.0 International License, which permits use, sharing, adaptation, distribution and reproduction in any medium or format, as long as you give appropriate credit to the original author(s) and the source, provide a link to the Creative Commons licence, and indicate if changes were made. The images or other third party material in this article are included in the article's Creative Commons licence, unless indicated otherwise in a credit line to the material. If material is not included in the article's Creative Commons licence and your intended use is not permitted by statutory regulation or exceeds the permitted use, you will need to obtain permission directly from the copyright holder. To view a copy of this licence, visit http://creativecommons. org/licenses/by/4.0/.

Publisher's Note Springer Nature remains neutral with regard to jurisdictional claims in published maps and institutional affiliations.

The original article can be found online at https:// doi.org/10.1007/s00500-022-06785-7.

Roberto Musmanno

roberto.musmanno@unical.it

Annarita De Maio

annarita.demaio@unical.it

Francesca Vocaturo

vocaturo@unical.it

1 Department of Mechanical, Energy and Management Engineering - DIMEG, University of Calabria, Via P. Bucci, Cubo 41C, 87036 Arcavacata di Rende, CS, Italy

2 Department of Economics, Statistics and Finance "Giovanni Anania” - DESF, University of Calabria, Via P. Bucci, Cubo 0C, 87036 Arcavacata di Rende, CS, Italy

3 Present Address: Department of Economics, Statistics and Finance "Giovanni Anania" - DESF, University of Calabria, Via P. Bucci, Cubo 0C, 87036 Arcavacata di Rende, CS, Italy 